\title{
Impact of virtual chemistry laboratory instruction on pre-service science teachers' scientific process skills
}

\author{
Ayfer Mutlu $^{1 \mathrm{a}}$ and Burçin Acar Şeşen ${ }^{2}$ \\ ${ }^{1}$ Kurklareli University, Vocational School of Health Service, 39100, Kırklareli, Turkey \\ ${ }^{2}$ Istanbul University, Hasan Ali Yücel Education Faculty, Science Education Department, 34070, \\ Istanbul, Turkey
}

\begin{abstract}
This study aimed to investigate the impact of virtual chemistry laboratory instruction on pre-service science teachers' scientific process skills. For this purpose, eight laboratory activities related to chemical kinetic, chemical equilibrium, thermochemistry, acids-bases, and electrochemistry were developed. Those activities were performed in virtual laboratory environment by the pre-service teachers in the experimental group and in the real laboratory environment by $\mathrm{c}$ the preservice teachers in the control group during eight weeks. Scientific process skills test developed by Burns, Okey and Wise [3], and translated into Turkish by Ateş and Bahar [2] was used before and after the instructions for data collection. According to results, while there was no significant difference between pre-test mean scores $(U=133.500, p>0.05)$, significant difference between post-test mean scores was found in favour of experimental group $(U=76.000, p<0.05)$. In addition, while no significant difference between pre-test mean scores for each sub-dimension was found, significant difference between post-test mean scores for designing investigation and formulating hypothesis skills was found in favour of experimental group.
\end{abstract}

Keywords: acids-bases; chemical kinetic; chemical equilibrium; electrochemistry; scientific process skill; thermochemistry; virtual chemistry laboratory

\section{Introduction}

Scientific process skills are physical and mental skills which are used for collecting and organizing knowledge, explaining phenomenon, solving problems [4]. Promoting scientific process skills is one of the main purposes of science education [8]. Laboratory, which is an

\footnotetext{
a Corresponding author: ayferkaradas@gmail.com
} 
important part of science education, has an important role for promoting scientific process skills [7]. On the other hand, real laboratory applications have some limitation such as dangerous chemicals, expensive laboratory chemical and equipments, crowded classroom, laboratory safety etc. Virtual laboratory as an alternative environment to real laboratory provides active participation to each step of experiment [6], interactive instruction in / out of class [11], learning according to individual needs [9], safety learning environment and familiarity to experimental process [5] and gaining experimental skills [10].

Although, there have been various research on virtual chemistry laboratories in elementary and high school level, research related to undergraduate education, especially science teacher training are limited. There has been also limited number of study on investigating the effects of virtual laboratories on scientific process skills. In the research by Yang and Heh [11], the effect of virtual physics laboratory on students' scientific process skills was investigated. It was conducted by participation of one hundred fifty students who were randomly assigned to experimental and control groups. Virtual physics laboratory instruction was conducted in the experimental group and traditional laboratory activities were performed in the control group. Significant difference was found between groups' scientific process skills mean scores in favour of experimental group. Altun, Feyzioğlu and Demirağ [1] investigated the effect of virtual chemistry laboratory instruction on high school students' scientific process skills. According to their results, it was found that virtual chemistry laboratory was more effective than traditional laboratory instruction for promoting students' scientific process skills.

\section{Method}

\subsection{Purpose of the research}

This study aimed to investigate the impact of virtual chemistry laboratory instruction on first grade pre-service science teachers' scientific process skills.

\subsection{Participants}

The participants of this study consisted of 34 first-year pre-service science teachers in a faculty of education sited in Istanbul, Turkey. The pre-service science teachers were from different cities in Turkey and they were randomly assigned to Experimental $(\mathrm{N}=17)$ and Control Groups $(\mathrm{N}=17)$. While laboratory activities were accomplished via virtual chemistry laboratory software in the Experimental Group, same activities were performed in the Control Group in the real laboratory environment.

\subsection{Instrument}

Scientific process skills test was used for identify pre-service science teachers' scientific process skills. The test was developed by Burns, Okey and Wise [3], and it was translated and adopted into Turkish by Ateş and Bahar [2]. Reliability coefficient was calculated to be 0.74. One point was given for item was correctly answered, and zero point was given for an item was incorrectly answered. It was consisted of 36 multiple-choice items and five scientific process skills measured by the related items (Table 1). 
Table 1.Distrubiton of items according to scientific process skills

\begin{tabular}{ll}
\hline Scientific process skills & Items \\
\hline Identifying Variables & $1,3,13,14,15,18,19,20,30,31,32,36$ \\
Defining Operationally & $2,7,22,23,26,33$ \\
Formulating Hypothesis & $4,6,8,12,16,17,27,29,35$ \\
Data and Graph Interpretation & $5,9,11,25,28,34$ \\
Designing Investigation & $10,21,24$ \\
\hline
\end{tabular}

\subsection{Procedure}

In the first step of research, students' understanding and learning difficulties were determined and learning objectives were constructed. Then, eight laboratory activities related to chemical kinetic, chemical equilibrium, thermochemistry, acids-bases, and electrochemistry were developed. Virtual chemistry laboratory software was developed for the same laboratory activities. In the first step, activities were conducted and recorded in real laboratory environment. Therefore, it was determined software content, steps of experiments and results. After the software content was developed, interface, experimental materials and equipment necessary for the virtual chemistry laboratory were modelled. Experimental materials and equipment were compared pictures in books and in website of Republic of Turkey Ministry of National Education Making Course Material Centre (http://daym.meb.gov.tr/). Virtual chemistry laboratory software was developed according to ADDIE instructional design model including analysis, design, development, implementation and evaluation steps. While developing virtual chemistry laboratory, HTML5, CSS3, PHP, MySQL, Adobe Flash Action Script 3.0, jQuery programs and applications were used. Activities and software were reviewed by two chemistry educators and one computer educator and it was piloted with five pre-service science teachers.

Treatments were conducted by participation of thirty-four pre-service science teachers, which were randomly assigned to Experimental Group ( $\mathrm{N}=17)$ and Control Group $(\mathrm{N}=17)$. While laboratory activities were accomplished via virtual chemistry laboratory software in the Experimental Group, same activities were performed in the Control Group in the real laboratory environment during eight weeks. Scientific process skills test was used before and after the instructions for data collection.

\section{Results}

In this research, nonparametric statistic tests were used for data analysis. Comparisons of groups' pre-test scores and groups' post-test scores were done by using Mann Whitney U test. Wilcoxon Signed Ranks test were used to identify differences between groups' pre-test and post-test scores.

Table 2. Mann Whitney U test results of the pre-test and post scientific process skills test

\begin{tabular}{lllllll}
\hline Test & Group & $\mathrm{N}$ & Mean of Ranks & Sum of Ranks & $\mathrm{U}$ & $\mathrm{p}$ \\
\hline Pre-Test & Experimental Group & 17 & 18.15 & 308.50 & 133.500 & 0.708 \\
& Control Group & 17 & 16.85 & 286.50 & & \\
\hline Post-Test & Experimental Group & 17 & 21.53 & 366.00 & 76.000 & 0.018 \\
& Control Group & 17 & 13.47 & 229.00 & & \\
\hline
\end{tabular}


According to Mann Whitney U test results, while no significant difference between pretest mean scores of groups was found $(\mathrm{U}=133.500, \mathrm{p}>0.05)$, significant difference between post-test mean scores $(\mathrm{U}=76.000, \mathrm{p}<0.05)$ was found in favour of Experimental Group (Table 2).

Table 3. Wilcoxon Signed Rank test results of the pre-test and post scientific process skills test

\begin{tabular}{lllllll}
\hline Test & Group & $\mathrm{N}$ & Mean of Ranks & Sum of Ranks & $\mathrm{z}$ & $\mathrm{p}$ \\
\hline Experimental & Negative Rank & 3 & 9.00 & 27.00 & $-2.122^{*}$ & 0.034 \\
Group & Positive Rank & 13 & 8.38 & 109.00 & & \\
& Ties & 1 & & & & \\
\hline Control Group & Negative Rank & 6 & 10.33 & 62.00 & $-0.311^{*}$ & 0.755 \\
& Positive Rank & 10 & 7.40 & 74.00 & & \\
& Ties & 1 & & & & \\
\hline
\end{tabular}

*Based on negative rank

As seen in Table 3, Wilcoxon Signed Rank Test results underlined that there was significant difference between pre and post test scores of Experimental Group in favour of post test $(\mathrm{z}=-2.122, \mathrm{p}<0.05)$ and no significant differences pre and post test scores of Control Group $(\mathrm{z}=-0.311, \mathrm{p}>0.05)$.

Table 4. Mann Whitney U test results of the pre-test and post scientific process skills test for subdimensions

\begin{tabular}{|c|c|c|c|c|c|c|c|}
\hline Skills & Test & Group & $\mathrm{N}$ & $\begin{array}{l}\text { Mean of } \\
\text { Ranks }\end{array}$ & $\begin{array}{l}\text { Sum of } \\
\text { Ranks }\end{array}$ & $\mathrm{U}$ & $\mathrm{p}$ \\
\hline Designing & Pre- & Experimental Group & 17 & 19.21 & 326.50 & 115.500 & 0.290 \\
\hline \multirow[t]{3}{*}{ Investigation } & Test & Control Group & 17 & 15.79 & 268.50 & & \\
\hline & Post- & Experimental Group & 17 & 20.94 & 356.00 & 86.000 & 0.029 \\
\hline & Test & Control Group & 17 & 14.06 & 239.00 & & \\
\hline \multirow{4}{*}{$\begin{array}{l}\text { Formulating } \\
\text { Hypothesis }\end{array}$} & Pre- & Experimental Group & 17 & 18.26 & 310.50 & 131.500 & 0.645 \\
\hline & Test & Control Group & 17 & 16.74 & 284.50 & & \\
\hline & Post- & Experimental Group & 17 & 22.09 & 375.50 & 66.500 & 0.006 \\
\hline & Test & Control Group & 17 & 12.91 & 219.50 & & \\
\hline \multirow{4}{*}{$\begin{array}{l}\text { Identifying } \\
\text { Variables }\end{array}$} & Pre- & Experimental Group & 17 & 17.85 & 303.50 & 138.500 & 0.832 \\
\hline & Test & Control Group & 17 & 17.15 & 291.50 & & \\
\hline & Post- & Experimental Group & 17 & 19.21 & 326.50 & 115.500 & 0.312 \\
\hline & Test & Control Group & 17 & 15.79 & 268.50 & & \\
\hline \multirow{4}{*}{$\begin{array}{l}\text { Data and } \\
\text { Graph } \\
\text { Interpretation }\end{array}$} & Pre- & Experimental Group & 17 & 16.74 & 284.50 & 131.500 & 0.643 \\
\hline & Test & Control Group & 17 & 18.26 & 310.50 & & \\
\hline & Post- & Experimental Group & 17 & 20.79 & 353.50 & 88.500 & 0.044 \\
\hline & Test & Control Group & 17 & 14.21 & 241.50 & & \\
\hline \multirow{4}{*}{$\begin{array}{l}\text { Defining } \\
\text { Operationally }\end{array}$} & Pre- & Experimental Group & 17 & 17.85 & 303.50 & 138.500 & 0.831 \\
\hline & Test & Control Group & 17 & 17.15 & 291.50 & & \\
\hline & Post- & Experimental Group & 17 & 20.65 & 351.00 & 91.000 & 0.059 \\
\hline & Test & Control Group & 17 & 14.35 & 244.00 & & \\
\hline
\end{tabular}

In addition, while no significant difference was found between pre-test mean scores for each sub-dimension, significant difference was found between post-test mean scores for designing investigation $(\mathrm{U}=86.000, \mathrm{p}<0.05)$ and formulating hypothesis skills $(\mathrm{U}=66.500$, $\mathrm{p}<0.05)$ in favour of Experimental Group (Table 4).

According to the Wilcoxon Signed Rank Test results, it was obtained that there were significant differences between Experimental Group's pre and post test scores for sub- 
dimensions as data and graph interpretation $(\mathrm{z}=-1.983, \mathrm{p}<0.05)$ and defining operationally $(\mathrm{z}=-2.738, \mathrm{p}<0.05)$ skills (Table 5).

Table 5. Wilcoxon Signed Rank test results of the pre-test and post scientific process skills test

\begin{tabular}{|c|c|c|c|c|c|c|c|}
\hline Skills & Test & Group & $\mathrm{N}$ & $\begin{array}{l}\text { Mean of } \\
\text { Ranks }\end{array}$ & $\begin{array}{l}\text { Sum of } \\
\text { Ranks }\end{array}$ & $\mathrm{z}$ & $\mathrm{p}$ \\
\hline \multirow{8}{*}{$\begin{array}{l}\text { Designing } \\
\text { Investigation }\end{array}$} & \multirow{4}{*}{$\begin{array}{l}\text { Experimental } \\
\text { Group }\end{array}$} & Negative Rank & 3 & 5.17 & 15.50 & \multirow{4}{*}{$\begin{array}{l}- \\
1.244^{*}\end{array}$} & \multirow[t]{4}{*}{0.214} \\
\hline & & & & & & & \\
\hline & & Positive Rank & 7 & 5.64 & 39.50 & & \\
\hline & & Ties & 7 & & & & \\
\hline & \multirow{4}{*}{$\begin{array}{l}\text { Control } \\
\text { Group }\end{array}$} & Negative Rank & 5 & 7.20 & 36.00 & \multirow{4}{*}{$\overline{0}-683 *$} & \multirow{4}{*}{0.495} \\
\hline & & & & & & & \\
\hline & & Positive Rank & 8 & 6.88 & 55.00 & & \\
\hline & & Ties & 4 & & & & \\
\hline \multirow{8}{*}{$\begin{array}{l}\text { Formulating } \\
\text { Hypothesis }\end{array}$} & \multirow{4}{*}{$\begin{array}{l}\text { Experimental } \\
\text { Group }\end{array}$} & Negative Rank & 7 & 8.21 & 57.50 & \multirow{4}{*}{$-\bar{c}$} & \multirow[t]{4}{*}{0.579} \\
\hline & & & & & & & \\
\hline & & Positive Rank & 9 & 8.72 & 78.50 & & \\
\hline & & Ties & 1 & & & & \\
\hline & \multirow{4}{*}{$\begin{array}{l}\text { Control } \\
\text { Group }\end{array}$} & Negative Rank & 11 & 7.50 & 82.50 & \multirow{4}{*}{$-\overline{1.295^{*}}$} & \multirow[t]{4}{*}{0.195} \\
\hline & & & & & & & \\
\hline & & Positive Rank & 4 & 9.38 & 37.50 & & \\
\hline & & Ties & 2 & & & & \\
\hline \multirow{8}{*}{$\begin{array}{l}\text { Identifying } \\
\text { Variables }\end{array}$} & \multirow{4}{*}{$\begin{array}{l}\text { Experimental } \\
\text { Group }\end{array}$} & Negative Rank & 4 & 11.50 & 46.00 & \multirow{4}{*}{$-\overline{1.149 *}$} & \multirow[t]{4}{*}{0.251} \\
\hline & & & & & & & \\
\hline & & Positive Rank & 12 & 7.50 & 90.00 & & \\
\hline & & Ties & 1 & & & & \\
\hline & \multirow{4}{*}{$\begin{array}{l}\text { Control } \\
\text { Group }\end{array}$} & Negative Rank & 6 & 7.42 & 44.50 & \multirow{4}{*}{$\begin{array}{l}- \\
0.887 *\end{array}$} & \multirow[t]{4}{*}{0.375} \\
\hline & & & & & & & \\
\hline & & Positive Rank & 9 & 8.39 & 75.50 & & \\
\hline & & Ties & 2 & & & & \\
\hline \multirow{8}{*}{$\begin{array}{l}\text { Data and } \\
\text { Graph } \\
\text { Interpretation }\end{array}$} & \multirow{4}{*}{$\begin{array}{l}\text { Experimental } \\
\text { Group }\end{array}$} & Negative Rank & 3 & 8.50 & 25.50 & \multirow{4}{*}{$-\overline{1.983 *}$} & \multirow[t]{4}{*}{0.047} \\
\hline & & & & & & & \\
\hline & & Positive Rank & 12 & 7.88 & 94.50 & & \\
\hline & & Ties & 2 & & & & \\
\hline & Control & Negative Rank & 6 & 9.50 & 57.00 & - & 0.773 \\
\hline & Group & & & & & $0.288^{*}$ & \\
\hline & & Positive Rank & 8 & 6.00 & 48.00 & & \\
\hline & & Ties & 3 & & & & \\
\hline Defining & Experimental & Negative Rank & 2 & 3.50 & 7.00 & - & 0.006 \\
\hline Operationally & Group & & & & & $2.738^{*}$ & \\
\hline & & Positive Rank & 11 & 7.64 & 84.00 & & \\
\hline & & Ties & 4 & & & & \\
\hline & Control & Negative Rank & 7 & 8.43 & 59.00 & - & 0.676 \\
\hline & Group & & & & & $0.417 *$ & \\
\hline & & Positive Rank & 7 & 6.57 & 46.00 & & \\
\hline & & Ties & 3 & & & & \\
\hline
\end{tabular}

*Based on negative rank

\section{Discussion}

This study aimed to investigate the impact of virtual chemistry laboratory instruction on first grade pre-service science teachers' scientific process skills. According to the results, it was found that there was significant difference between groups' post-test mean scores in favour of Experimental Group. Also, there was significant difference between groups' posttest mean scores for designing investigation and formulating hypothesis skills in favour of Experimental Group. Results underlined that virtual chemistry laboratory is effective 
instruction for promoting pre-service science teachers' scientific process skills especially designing investigation and formulating hypothesis skills.

These results can be explained that virtual chemistry laboratory provided a different, interesting, rich visual content, safety experimental environment, simulating a real laboratory environment and familiarity with laboratory procedures for pre-service science teachers. Also, virtual chemistry laboratory was developed to provide choosing and set up experimental materials, conducting experiments themselves, prediction results, data collection and note it, draw graphs and interpretation their results. Virtual chemistry laboratory provided that using their scientific process skills in cooperative environment to pre-service science teachers. Therefore, this virtual learning environment was effective for using, gaining and promoting scientific process skills. In addition to these, pre-service science teachers were taught based on traditional approach from elementary school. So, they were familiar laboratory activities based on traditional methods. For this reason, virtual chemistry laboratory instruction was different and interesting learning environment for pre-service science teachers in experimental group. This situation was effective that experimental group more focus to instruction than control group. Moreover, previous studies highlighted that virtual laboratory environment increased students' scientific process skills. Altun, Feyzioğlu and Demirağ [1] were found that virtual chemistry laboratory more promoted than traditional laboratory ninth and eleventh grade students' scientific process skills similarly our results. Yang and Heh [11] was underlined that virtual physics laboratory instruction more effective than traditional laboratory instruction for increasing students' scientific process skills, these coherent our findings.

In conclusion, virtual chemistry laboratory instruction can be used for promoting scientific process skills as an alternative to real chemistry laboratory.

\section{References}

1. Altun, E. H., Feyzioğlu, B., \& Demirăg, B. Liseler için yapılandırmacı öğrenme etkinlikleri ile zenginleştirilmiş etkileşimli sanal kimya laboratuvarı geliştirilmesi. TUBITAK project, number of 108K293., (2011).

2. Ateş, S. \& Bahar, M. Araştırmacı Fen Öğretimi Yaklaşımıyla Sınıf Öğretmenliği 3. Sınıf Öğrencilerinin Bilimsel Yöntem Yeteneklerinin Geliştirilmesi. V. Ulusal Fen ve Matematik Eğitimi Kongresi, 16-18 September, Ankara., (2002).

3. Burns, J. C., Okey, J. C. \& Wise, K. Development of an integrated process skills test: TIPS II. Journal of Research in Science Teaching, 22(2), 169-177., (1985).

4. Carin, A. A., \& Bass, J. E. Methods for teaching science as inquiry. Prentice Hall: USA, (2001).

5. Dalgarno, B., Bishop, A., G. \& Bedgood J., D., R. The potential of VL. for distance education science teaching: reflections from the development and evaluation of a virtual chemistry laboratory, Uniserve Science Improving Learning Outcomes Symposium, Sydney, Proceedings Book, 90-95., (2003).

6. Dede, C.J., Salzman, M. \& Loftin R.,B. The development of a virtual world for learning newonian mechanics. Multimedia, Hypermedia, and Virtual Reality-Models, Systems, and Application First International Conference, Moscow-Russia., (1994).

7. Hofstein, A., \& Mamlok-Naaman, R. The laboratory in science education: the state of the art. Chemistry education research and practice, 8(2), 105-107., (2007).

8. Huppert, J.,Lomask, S. M., \& Lazarowitz, R. Computer simulations in the high school: students' cognitive stages, science process skills and academic achievement in microbiology. International Journal of Science Education, 24, 803-821., (2002). 
9. Stieff, M. \& Wilensky, U. Connected chemistry-incorporating interactive simulations into the chemistry classroom, Journal of Science Education and Technology, 12, 3., (2003).

10. Subramanian, R. and Marsic, I. VIBE: Virtual biology experiments., (2001). Retrieved date: 26.04.2015, Retrieved from: http://www10.org/cdrom/papers/513/

11. Yang, K., Y. \& Heh, J., S. The impact of internet virtual physics laboratory instruction on the achievement in physics, science process skills and computer attitudes of 10th grade students, Journal of Science Education and Technology, 16, 451-461., (2007). 